\title{
Productivity Enhancement Technology Dissemination for Groundnut Grown in Koppal District of Karnataka through Cluster Frontline Demonstrations
}

\author{
R. Jyothi*, Raghavendra Yaligar, J. Radha, C. M. Kalibavi, \\ D. H. Roopashree and Mamatha Madli \\ ICAR- KrishiVigyan Kendra, Koppal-583227, Karnataka, India \\ *Corresponding author
}

\section{A B S T R A C T}

Keywords

Cluster

demonstration,

Productivity,

Groundnut,

Technology

Article Info

Accepted:

20 August 2019

Available Online:

10 September 2019
Groundnut is an important oilseed crop widely consumed in India, which plays a major role in supplementing the income of farmers. The cluster frontline demonstration (CFLD) was conducted by the ICAR- Krishi Vigyan Kendra, Koppal (Karnataka) with improved variety and package of practices in summer groundnut cultivation for two years (Summer, 2017-18 and 2018-19).The pod yield of summer groundnut crop was increased by demonstrating the improved variety and cultivation technologies at the farmer's field under the supervision of scientists working in the operational area. During this period of study it was observed that improved variety(G-2-52) of demonstration recorded higher pod yield (12.35 and 13.57q/ha) than the farmer's variety (Local check), where per cent increase in the yield was accounted 32.89 and 28.54 per cent for the year 2018-18 and 2018-19 respectively. The cluster front line demonstration were carried out in a systematic manner on farmer's field to show the worth of a new variety and convincing farmers about potentialities of improved variety and production management practices of summer groundnut for further adoption

\section{Introduction}

Groundnut (Arachis hypogaea L.) is an important leguminous food and oilseed crop grown by small and marginal farmers in diverse agro-environments in India. It occupies an area of 4.15 million ha with productivity of around $1704 \mathrm{~kg} / \mathrm{ha}(2017-18)$ in India. In view of the increasing population and anticipated climate change, production must continue to increase to meet the current and future demand for edible oil and vegetable protein of the country. The crop is mainly grown under three situations viz., kharif, rabi/summer and residual moisture conditions on riverbeds (Satish Kumar et al., 2004).The country accounts for 12-15 percent of global oilseeds area, 6-7 per cent of vegetable oils production, and 9-10 per cent of the total edible oils consumption (FAO, 2011).It is grown in semi-arid regions of India, especially in the states of Gujarat, Andhra Pradesh, 
Rajasthan, Karnataka and Maharashtra. Among the total oilseed crops in Karnataka, groundnut occupied an area of 378 thousand ha with productivity of $874 \mathrm{~kg} / \mathrm{ha}(2017-18)$.

The Koppal district has been considered as potential region of groundnut due to favorable soil and climate conditions and precise irrigation management through sprinkler.

In the district lack of suitable high yielding variety as well as poor knowledge about critical production practices are the main reasons for low productivity of summer groundnut.

Awareness of scientific production technology like seed treatment with fungicide, insecticide and biofertilizers, use of sulphur which is important nutrient for oilseed crops is lacking in Koppal district which was a key reason for low productivity of groundnut.

The production potential could be increased by adopting recommended scientific and sustainable management production practices with improved high yielding varieties and other critical input through cluster frontline demonstration (CFLD).

The productivity of summer groundnut area could be increased by adopting recommended scientific and sustainable management practices using a suitable high yielding variety.

Taking into account the above considerations cluster front line demonstration were carried out in a systematic manner on farmer's fields of major groundnut growing area of koppal district to show the worth of a new variety with integrated crop management practices and convincing farmers to adopt integrated crop management technology of summer groundnut for enhancing productivity of groundnut.

\section{Materials and Methods}

The study was conducted in Gangavathi taluk, Koppal district of Karnataka. The Frontline demonstrations were organized on farmer's field to demonstrate the impact of integrated crop management technology on Groundnut productivity over two years during summer 2017 and 2018. The CFLD's under summer groundnut crop was laid out in the four villages, namely Gudlanuru, Chikkabommanala, Kuduremoti and Beluru. Each frontline demonstration was laid out on 0.4 ha area, adjacent 0.4 ha was considered as control for comparison (farmer's practice).

The integrated crop management technology comprised the improved variety G-2-52, proper tillage, proper seed rate, pre-emergent weedicide application, seed treatment with bio fertilizers and Trichodrema, proper nutrient and pest management (Table 1).

Regular visits by the KVK scientists to demonstration field were ensured and made to guide the farmers. These visits were also utilized to collect feedback information's for further improvement in research and extension programmes. Field days and group meeting were also organized at the demonstration sites to provide the opportunities for other farmers to witness the benefits of demonstrated technologies. The CFLD was conducted to study the technology gap between the potential yield and demonstrated yield, extension gap between demonstrated yield and yield under existing practice and technology index.

The yield data were collected from both the demonstration and farmers practice by random crop cutting method and analyzed by using simple statistical tools. The technology gap, extension gap and technological index (Samui et al., 2000) were calculated by using following formula as given below: 


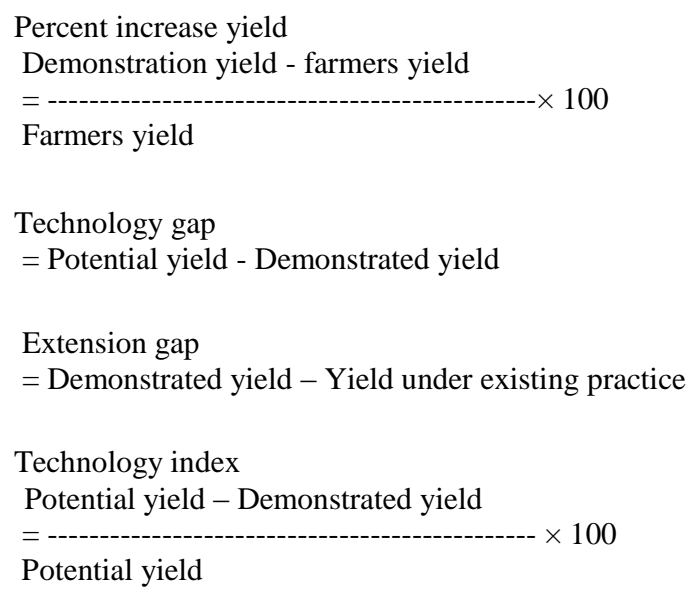

\section{Results and Discussion}

The criteria's taken for improved practices and compared to Farmers practices for summer groundnut under CFLD is present in Table 1.

Full gap was observed in case of use of variety, sowing method, seed treatment, plant protection and weed management and partial gap was observed in fertilizer dose, which definitely was the reason of not achieving potential yield. Farmers were not aware about much of the recommended technologies. Farmers in general used local or old varieties instead of the recommended high yielding resistant varieties. Unavailability of seed in time and lack of awareness were the main reasons. Farmers followed thick sowing against the recommended line sowing and because of this, they applied higher seed rate than the recommended.

\section{Yield and Economic benefits}

Yield and economic benefit of Groundnut variety G2-52 through cluster demonstration is presented in Table 2.

\section{Yield}

During two years of frontline demonstrations results obtained are presented in table 2 . The results revealed that due to front line demonstration on groundnut an average yield was recorded $12.96 \mathrm{q} / \mathrm{ha}$ under demonstrated plots as compared farmers practice $9.93 \mathrm{q} / \mathrm{ha}$ during the year 2017-18. The highest yield in the FLD plot was 13.57q/ha in 2018-19 and in farmers practice $10.56 \mathrm{q} / \mathrm{ha}$ in the same year. This results clearly indicated that the higher average pod yield in demonstration plots over the years compare to local check due to knowledge and adoption of full package of practices i.e. appropriate varieties such as G-252 etc., timely sowing, seed treatment with Bio fertilizers (Rhizobium and PSB),Trichoderma @ $4 \mathrm{~g} / \mathrm{kg}$ of seed, use of balanced dose of fertilizer $(25 \mathrm{~kg}, 50 \mathrm{~kg}$ P2O5and $25 \mathrm{~kg}$ K2O per ha), Gypsum, method and time of sowing, timely weed management, need based plant protection, optimum plant population, reduced competition for nutrient, moisture, sunlight and proper grading of the pods. The average yield of groundnut increased 30.51 percent. The yield of groundnut could be increased over the yield obtained under farmers practices (old variety, no use of the balanced dose of fertilizer, untimely sowing and no control measure adopted for pest management) of Groundnut cultivation. The above findings are in similarity with the findings of Solanki and Khatik (2013), Dhaka et al., (2010), Patil et al.,(2010), Yadav et al., (2007) and Chaniyara et al., (2001)

\section{Economic return}

The inputs and outputs prices of commodities prevailed during the study of demonstration were taken for calculating net return and benefit: cost ratio (Table 2). The cultivation of groundnut under improved technologies gave higher net return of Rs.23,169, and 26,856 per ha respectively as compared to farmers practices. Similar findings were reported by Rajuteggelli et al., (2015). The benefit cost ratio of groundnut cultivation under improved cultivation practices were 1.89 in each year 
whereas 1.53 and 1.8 under farmers practices in respective years. This may be due to higher yield obtained under improved technologies compared to local check (farmers practice). This finding is in corroboration with the findings of Mokidue et al., (2011).

Table.1 The criteria's taken for improved practices and compared to Farmers practices for summer groundnut under CFLD

\begin{tabular}{|c|c|c|c|c|}
\hline Sl. No. & Technology & Improved practices & Farmers practices & Gap \% \\
\hline 1. & Variety & G-2-52 $=$ & Local variety & 100 \\
\hline 2. & Land preparation & Ploughing and harrowing & $\begin{array}{l}\text { Ploughing and } \\
\text { harrowing }\end{array}$ & Nil \\
\hline 3. & $\begin{array}{l}\text { Pre-emergent } \\
\text { application }\end{array}$ & $\begin{array}{l}\text { Apply Pendimethalin } 30 \text { EC } \\
\text { @ } 3.0 \text { lt/ha }\end{array}$ & - & Full gap \\
\hline 4. & Seed rate & $60 \mathrm{~kg}$ & $60 \mathrm{~kg}$ & Nil \\
\hline 5. & Sowing method & Line sowing & Line sowing & Nil \\
\hline 6. & Seed treatment & $\begin{array}{l}\text { With bio fertilizers and } \\
\text { Trichoderma }\end{array}$ & - & Full gap \\
\hline 7. & Fertilizer dose & $25: 50: 25$ & $40: 80: 40$ & Partial gap \\
\hline 8. & Plant protection & IPM & $\begin{array}{l}\text { Indiscriminate } \\
\text { application }\end{array}$ & Full gap \\
\hline 9. & $\begin{array}{l}\text { Grading the } \\
\text { produce }\end{array}$ & Grading the produce & Not followed & Full gap \\
\hline
\end{tabular}

CFLD: Cluster Frontline demonstration

Table.2 Yield and economic benefit of Groundnut variety G2-52 through cluster demonstration

\begin{tabular}{|c|c|c|c|c|c|c|c|c|c|}
\hline \multirow[t]{2}{*}{ Year } & \multirow{2}{*}{$\begin{array}{l}\text { No. of } \\
\text { Demo }\end{array}$} & \multirow[t]{2}{*}{ Area (ha) } & \multicolumn{2}{|c|}{ Yield (q/ha) } & \multirow{2}{*}{$\begin{array}{c}\% \\
\text { increase }\end{array}$} & \multicolumn{2}{|c|}{ Net return } & \multicolumn{2}{|c|}{ B:C ratio } \\
\hline & & & Demo & Check & & Demo & Check & Demo & Check \\
\hline 2017-18 & 75 & 30 & 12.35 & 9.29 & 32.89 & 23,169 & 12,923 & 1.89 & 1.53 \\
\hline 2018-19 & 75 & 30 & 13.57 & 10.56 & 28.54 & 26,856 & 19,706 & 1.89 & 1.8 \\
\hline Average & 75 & 30 & 12.96 & 9.93 & 30.72 & 25,013 & 16,315 & 1.89 & 1.67 \\
\hline
\end{tabular}

Table.3 Performance of Groundnut var. G-2-52 on Technological gap, Extension gap and Technology index through demonstration of integrated crop management technologies

\begin{tabular}{|l|l|l|l|l|l|l|}
\hline Year & $\begin{array}{l}\text { No. of } \\
\text { Demo }\end{array}$ & $\begin{array}{l}\text { Area } \\
\text { (ha) }\end{array}$ & $\begin{array}{l}\text { Potential } \\
\text { yield }(\mathbf{q} / \mathbf{h a})\end{array}$ & $\begin{array}{l}\text { Technological } \\
\text { gap }(\mathbf{q} / \mathbf{h a})\end{array}$ & $\begin{array}{l}\text { Extension gap } \\
(\mathbf{q} / \mathbf{h a})\end{array}$ & $\begin{array}{l}\text { Technology } \\
\text { index } \mathbf{( \% )}\end{array}$ \\
\hline $\mathbf{2 0 1 7 - 1 8}$ & 75 & 30 & 38 & 25.65 & 3.06 & 67.50 \\
\hline $\mathbf{2 0 1 8 - 1 9}$ & 75 & 30 & 38 & 23.43 & 3.01 & 61.66 \\
\hline Average & 75 & 30 & 38 & 24.54 & 3.04 & 64.58 \\
\hline
\end{tabular}




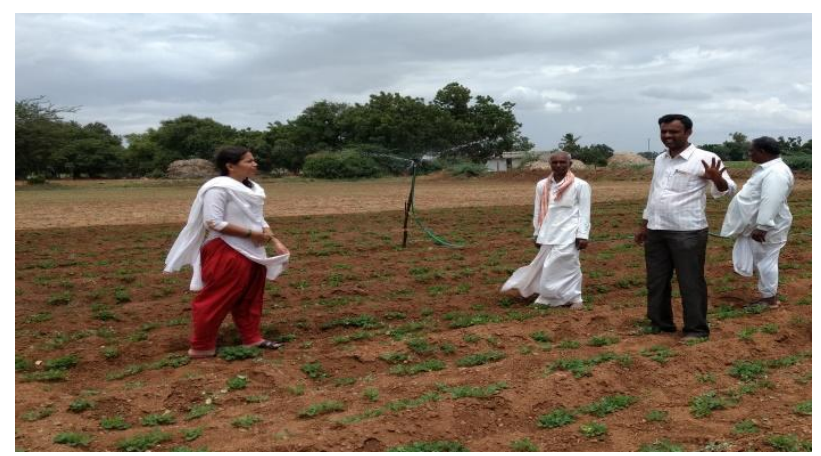

Instruction about uses of sprinkler and nutrient management during initial crop period in Groundnut

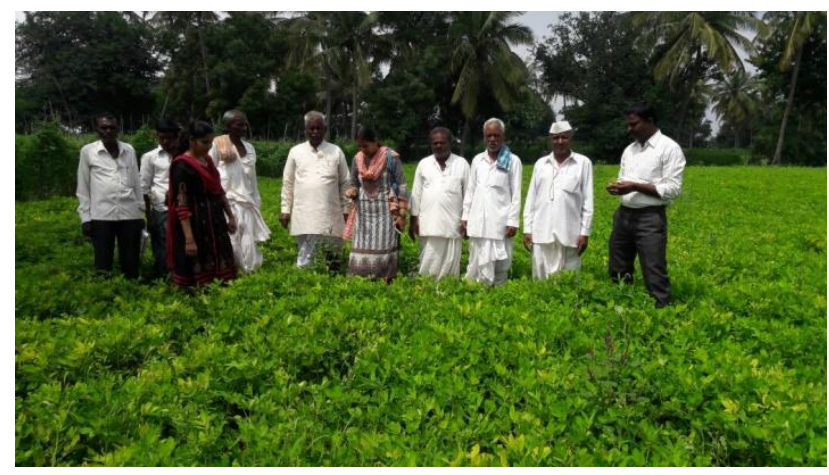

Instruction about Pest and disease management during mid of crop period in Groundnut

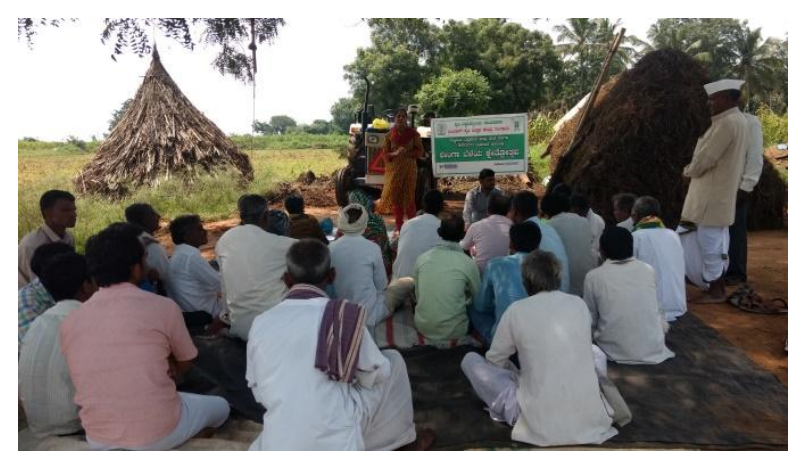

Conducted field day for horizontal spreading of the high yielding technology in Groundnut crop 
Technological gap, Extension gap and Technology index

Performance of Groundnut var. G-2-52 on Technological gap (q/ha), Extension gap (q/ha) and Technology index (\%) through demonstration of integrated crop management technologies is presented in Table 3.

\section{Technology gap (q/ha)}

The technology gap, the differences between potential yield and yield of demonstration plots were 25.65 and 23.43 q/ha during 201718 and 2018-19 respectively. On an average technology gap under two year FLD programme was $24.54 \mathrm{q} / \mathrm{ha}$. The technology gap observed may be related to dissimilarity in the soil fertility status, enriching soil nutrient with organic manures, agricultural practices and local climatic situation viz., rainfall and temperature (Dhandhalya et al., 2009).

\section{Extension gap (q/ha)}

Extension gap of 3.06 and $3.01 \mathrm{q} / \mathrm{ha}$ were observed during 2017-18 and 2018-19 respectively. On an average extension gap under two year FLD programme was 3.04 $\mathrm{q} / \mathrm{ha}$. Which emphasized the need to educate the farmers through various extension means i.e. front line demonstration for adoption of improved production and protection technologies, to revert the trend of wide extension gap. More and more use of latest production technologies with high yielding varieties will subsequently change this alarming trend of galloping extension gap.

\section{Technology Index (\%)}

The technology index shows the feasibility of the demonstrated technology at the farmers field. The technology index of67.50 and61.66 per cent were observed during 2017-18 and 2018-19 respectively. On an average technology index was observed 64.58 per cent during the two years of FLD programme, which shows the efficacy of good performance of technical interventions. This will accelerate the adoption of demonstrated technical intervention to increase the yield performance of groundnut.

The CFLD produces a significant positive result on productivity, economic returns to the farmers which on the other hand benefits in the Socio-economic status of groundnut grower. This demonstration also help to reduce Technological gap (q/ha), Extension gap (q/ha) and improve the Technology index (\%). Technology disseminations through Cluster FLD along with the ATMA and NGO's in a particular district is very much important to enhance the productivity of major oilseed crop groundnut which make understand farmer through method demonstration, training programme and field day.

\section{References}

Chaniyara, N.J., Solanki, R. M. and Bhalu, V.B. 2001.Response of summer groundnut to Sppacing and plant population. Legume Research-An international Journal, 24(4): 252-255

Dhaka B. L., Meena B.S. and Suwalka R. L., 2010. Popularization of improved maize production technology through front line demonstration in southeastern Rajasthan. J.Agric.Sci.,1(1):39-42.

Dhandhalya, M.G and Shiyani, R. L. 2009. Production potentials, yield gaps and research prioritization of production constrains in major oilseed crops of Saurashtra region. Indian Journalof Agricultural Research. 43(1):18-25.

Mokidue I., Mohanty A. K. and Sanjay K., 2011.Corelatinggrowth, yield and adoption of urd bean technologies. 
Indian J. Ex. Edu.11(2): 20-24.

PatilY. G., Mahajan S. J., Patil C. H., Deshetti A. S. and SarodeP.N., 2010. Front line demonstration - An effective tool for increasing the productivity of groundnut and soybean in

Jalgaon district of Maharastra. Internat. $J$. Agric. Sci., 6 (1):88-90.

RajuTeggelli G., ZaheerAhamed B., Basavaraj Biradarand Basayya, 2015. Productivity enhancement technology dissemination for chick pea grown in Kalaburgi district of Karnataka through frontline demonstrations, Eco. Env.\& Cons. 21: (S23-S26).

Samui S. K, Mitra S., Roy D. K., Mandal A. K. and Saha D. 2000. Evaluation of front line demonstration on groundnut. Journal of the Indian Society Costal
Agricultural Research.18(2):180-183.

Satish Kumar G. D., Dash M. M., Tripathy M. and Mohapatra D.,2004. Groundnut cultivation constraints in residual moisture condition. Agricultural Extension Review, 16(1): 26-28.

Solanki, R.L. and Khatik, C.L. 2013. Performance of HYV of summer groundnut through front line demonstration in Chittorgarh of Rajasthan. Internat. J. Plant Sci.,8(2): 466-467.

YadavV.P. S., Kumar R., Deshwal A. K., Raman R. S., Sharma B. K. and Bhela S.L., 2007. Boosting pulse production through front line demonstration. Indian Res. J. Extn.Edu.,7(2\&3):12-14.

\section{How to cite this article:}

Jyothi, R., Raghavendra Yaligar, J. Radha, C. M. Kalibavi, D. H. Roopashree and Mamatha Madli 2019. Productivity Enhancement Technology Dissemination for Groundnut Grown in Koppal District of Karnataka through Cluster Frontline Demonstrations. Int.J.Curr.Microbiol.App.Sci. 8(09):1833-1840. doi: https://doi.org/10.20546/ijcmas.2019.809.212 